Gut, 1972, 13, 634-637

\title{
Blood loss after partial gastrectomy
}

\author{
I. MCLEAN BAIRD ${ }^{1}$ AND D. R. SUTTON \\ From West Middlesex Hospital, Isleworth, Middlesex
}

SUMMARY Six male and three female patients previously iron deficient after a partial gastrectomy were investigated using a whole body counter to measure their percentage ${ }^{59} \mathrm{Fe}$ retention.

No significant difference in iron loss between postgastrectomy patients and controls was found in the majority of subjects over a study which lasted from 175 to 225 days. The detection of increased free iron loss requires a more sensitive double isotope faecal recovery method.

Two patients developed acute bleeding during the study and the whole body counter provided clinically useful data on blood loss.

If patients develop gastrointestinal blood loss after partial gastrectomy either a recurrent ulcer or a site of blood loss elsewhere (eg, in the lower bowel) should be excluded.

Iron-deficiency anaemia occurs frequently after partial gastrectomy and its incidence increases in relation to the duration of time after operation (Baird, Blackburn, and Wilson, 1959; Baird and Wilson, 1959). Iron absorption is impaired after partial gastrectomy but the role of blood loss or free iron loss in the anaemia after partial gastrectomy is still not clear. Kimber, Patterson, and Weintraub (1967) found increased faecal blood loss in the stools using a radiochromium labelled red cell technique in six out of eight patients after partial gastrectomy with untreated iron-deficiency anaemia. Holt, Gear, and Warner, (1970) in a study of patients over periods of up to three months, using a whole body counter to determine blood loss, concluded that abnormal bleeding was present in five patients who lost blood at a rate of over $150 \mathrm{ml}$ per month. Contrary evidence about blood loss after partial gastrectomy was found by Stevens, Pinzio-Biroli, Harkins, Nyhus, and Finch (1959) and Baird, St. John, and Nasser (1970) whose faecal radiochromium blood loss studies failed to show any increased blood loss either basal or after an aspirin challenge in partial gastrectomy subjects compared with controls.

The present study was designed to give further observations on the role of blood loss after partial gastrectomy, using a whole body counter (Warner and Oliver, 1966) in long-term measurements of whole body radioiron for periods up to 225 days. Control subjects and patients previously iron

\footnotetext{
${ }^{1}$ Requests for reprints to I.McL.B., West Middlesex Hospital, Isleworth, Middlesex.
}

Received for publication 20 June 1972. deficient after a Polya partial gastrectomy were measured at intervals after an intravenous injection of ${ }^{59} \mathrm{Fe}$.

\section{Patients and Methods}

Six male and three female patients were investigated. All had previously had a Polya partial gastrectomy between eight and 22 years before the study, and had been seen in hospital with iron-deficiency anaemia, confirmed by the absence of stainable bone marrow iron. Anaemia had developed between three and 18 years after the operation. Iron repletion was carried out with oral iron in most cases, and normal iron status and haemoglobin levels were achieved at least five months before the present observations. The clinical data of the patients studied are shown in Table I. Control subjects were former patients with chronic bronchitis, obesity, and other medical conditions with no evidence of anaemia, gastrointestinal disorder, or blood loss. The nature of the investigations was explained to the control subjects who agreed to volunteer for the long-term study. All subjects had a barium meal and follow-through examination to exclude any other cause of gastrointestinal blood loss. Patients were instructed not to take aspirin or any other drugs likely to induce gastrointestinal bleeding while on the study.

\section{Methods}

A Panax shadow shield scanning whole body counter similar to that described by Warner and Oliver (1966) was used to measure iron losses. After a 
basal count a sample of the patient's plasma was labelled with 10 microcuries of ${ }^{59} \mathrm{Fe}$ as ferric citrate and re-injected. The patients were then recounted and subsequently counted at weekly intervals for one month and then every three weeks over the remaining period. The patients and control subjects were counted over periods of 175 to 225 days and the ratios of the patients' counts to the standard ${ }^{50} \mathrm{Fe}$ counts were related to the initial $100 \%$ value obtained on the day of injection to give the percentage retention. The ${ }^{59} \mathrm{Fe}$ activity in the blood 10 days after injection was related to the injected dose in order to calculate the percentage of ${ }^{59} \mathrm{Fe}$ utilized by the red cells.

\section{Results}

The clinical features of the nine patients are shown in Table I together with their mean percentage daily iron losses. The fall in radioactivity in the postgastrectomy group over the entire period was similar to that observed in the control subjects, with the exception of two patients who both had frank blood loss, one from bleeding haemorrhoids and the other from gastrointestinal bleeding causing melaena, possibly from a recurrent ulcer. There was no significant difference between the fall in whole body radioiron activity between normal subjects and postgastrectomy subjects except when overt blood loss occurred. The mean percentage ${ }^{59} \mathrm{Fe}$ loss per day in the control subjects was $0.028 \pm 0.012$ and com- pared with $0.021 \pm 0.014$ in the seven postgastrectomy subjects who did not have a frank haemorrhage. The length of the studies varied from 175 to 225 days (Table II).

\begin{tabular}{llll}
\hline Group & $\begin{array}{l}\text { Mean Total } \\
\text { Calculated } \\
\text { Blood Loss }(\mathrm{ml})(\%)\end{array}$ & $\begin{array}{l}\text { 10-Day Mean } \\
\text { s\% Etilization Calculated }\end{array}$ & $\begin{array}{c}\text { Mean Daily } \\
\text { Blood Loss }(\mathrm{ml})\end{array}$ \\
\hline $\begin{array}{l}\text { Five controls } \\
\text { Seven postgastrec- } \\
\text { tomy }\end{array}$ & 164 & 75 & 0.76 \\
$\begin{array}{c}\text { One patient with } \\
\text { bleeding haemor- } \\
\text { rhoids }\end{array}$ & 133 & 86 & 0.52 \\
$\begin{array}{l}\text { One patient with GI } \\
\text { haemorrhage }\end{array}$ & 1760 & 84 & \\
\hline
\end{tabular}

Table III Total and daily blood loss in five controls, seven postgastrectomy patients, and two postgastrectomy patients with clinical blood loss

The mean daily blood loss was calculated, allowing for loss of red cells from initial blood sampling and based on the assumptions of Holt, Mayet, Warner, and Callender (1967). The mean daily blood loss was $0.52 \mathrm{ml}$ in seven postgastrectomy patients compared with $0.76 \mathrm{ml}$ in the five control subjects (Table III). The ${ }^{59} \mathrm{Fe}$ utilization over 10 days showed a higher utilization of $86 \%$ of the administered radioiron incorporated into the red cells in seven postgastrectomy patients than the $75 \%$ utilization in the five control subjects.

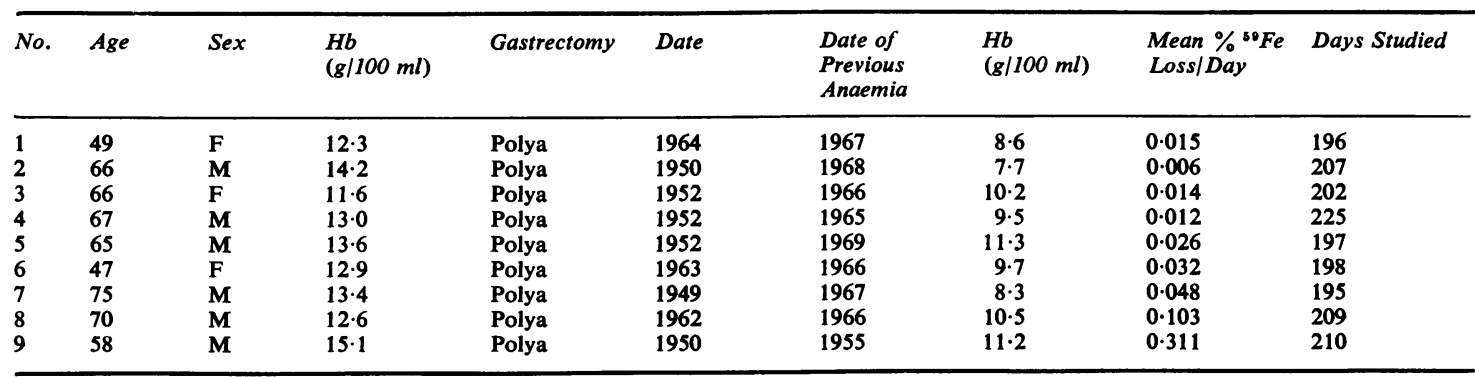

Table 1 Clinical features and iron loss in nine postgastrectomy patients

\begin{tabular}{|c|c|c|c|c|c|}
\hline Group & No. in Group & Mean Age & $\operatorname{sex}$ & $\begin{array}{l}\text { Mean Percentage }{ }^{59} \mathrm{Fe} \\
\text { Loss/Day } \pm S D\end{array}$ & Days Studied \\
\hline Controls & 5 & 44 & $\begin{array}{ll}3 & 0 \\
2 & +\end{array}$ & $0.028 \pm 0.012$ & $175-217$ \\
\hline Postgastrectomy & 9 & 62 & $\begin{array}{ll}6 & 0 \\
3 & 9\end{array}$ & $0.063 \pm 0.115$ & $195-225$ \\
\hline $\begin{array}{l}\text { Postgastrectomy (excluding } \\
\text { those with overt blood } \\
\text { loss) }\end{array}$ & 7 & 61 & $\begin{array}{ll}4 & 0 \\
3 & +\end{array}$ & $0.021 \pm 0.014$ & $195-225$ \\
\hline
\end{tabular}

Table 2 Whole body counting in postgastrectomy patients 


\section{Discussion}

There are at least three possible mechanisms for the occurrence of iron-deficiency anaemia after partial gastrectomy. Iron absorption defects (Baird et al, 1959; Turnberg, 1966), chronic blood loss and increased free iron loss after partial gastrectomy (Sutton, Baird, Stewart, and Coghill, 1970) may be due to the loss of iron in or with increased exfoliated gut epithelial cells. The role of continued or intermittent blood loss as a factor has been the subject of many conflicting reports. Kimber et al (1967) measured faecal blood loss and found it to be up to $6.5 \mathrm{ml} /$ day using radiochromium, but this was not confirmed even on aspirin challenge in a later report (Baird et al, 1970). Stevens et al (1959) found no evidence of excess blood loss in five out of seven patients over one year by following ${ }^{55} \mathrm{Fe}$ activity in the blood. The two patients who bled had other conditions; one had carcinoma of the vulva and the other had thrombocytosis. Faecal studies are limited by the difficulty that intermittent blood loss may be missed in some subjects. For this reason whole body counting techniques have some advantages in detecting blood loss.

Holt et al (1970) in a study of 11 postgastrectomy patients over approximately 14 weeks using the Oxford whole body counter found evidence suggesting increased blood loss in five patients and concluded that in this group bleeding from the gastric remnant is a frequent cause of iron deficiency. However, during this study approximately half of the patients had low haemoglobin levels at the time of investigation. The present study was made at least five months after iron repletion to try to ensure that the iron status of the patients and controls were comparable. The present study, made over a longer period, did not detect evidence of increased blood loss in the majority of the patients studied.

The mean loss of $0.028 \pm 0.012 \%$ per day of total body ${ }^{59} \mathrm{Fe}$ activity in the non-menstruating control subjects was comparable to the losses found in four control subjects by Holt et al (1967) and to that of the seven postgastrectomy patients in the present study.

The two previous studies which showed bleeding after partial gastrectomy (Kimber et al, 1967; Holt et al, 1970) were concerned with anaemic postgastrectomy subjects. It is possible that once iron deficiency develops from increased free iron loss and iron malabsorption, a third mechanism such as increased blood loss may develop. However, we found seven out of nine patients had no evidence of gastrointestinal blood loss, and our findings suggested that blood loss does not play a consistent role in the development of postgastrectomy iron-deficiency anaemia. If blood loss is found either by whole body counting or by the increased ${ }^{51} \mathrm{Cr}$-labelled red cells in the faeces then investigations should be directed towards excluding a recurrent ulcer or haemorrhage from the lower bowel. Repeated haemorrhage occurred from undetected haemorrhoids in case 8.

Since two of the female patients were premenopausal when they developed iron-deficiency anaemia, it is likely that blood loss was a factor in causing anaemia in a total of four out of the nine patients studied. The importance of blood loss is emphasized by the fact that anaemia developed within five years of operation in these four patients, but took five to 18 years to occur in those without evidence of blood loss.

The value of a whole body counter in detecting a sudden acute blood loss was shown in case 9 , where frank melaena developed during the study. This 58year-old man had a haemoglobin of $13.4 \mathrm{~g} / 100 \mathrm{ml}$ in January 1970, but had a melaena and the haemo-

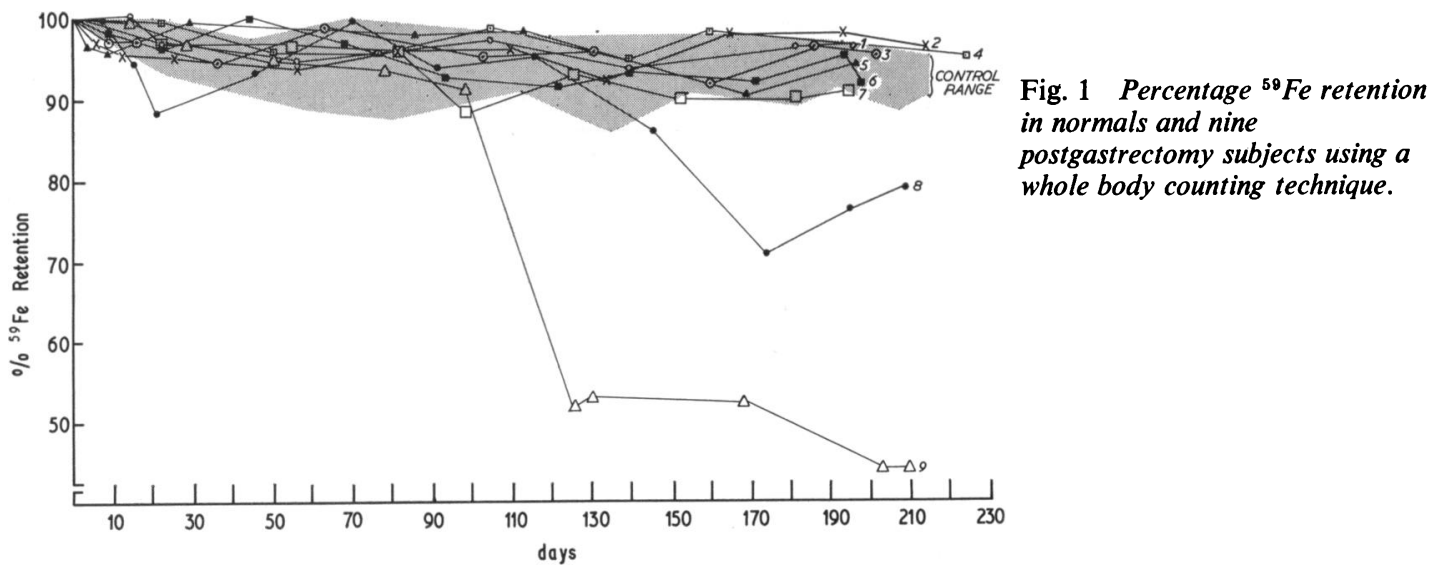


globin fell to $11.0 \mathrm{~g}$. The calculated loss of blood using a whole body counter was $1760 \mathrm{ml}$ (Fig. 1). He was considered to require a blood transfusion of 3 pints of whole blood. There was a later rise in haemoglobin on iron therapy (ferrous sulphate 200 $\mathrm{mg}$ three times daily) to $15 \cdot 1 \mathrm{~g} / 100 \mathrm{ml}$ in September 1970. The haemoglobin value has remained about this value for a subsequent year of follow up.

The relative insensitivity of the methods in detecting iron loss and the high initial utilization of ${ }^{59} \mathrm{Fe}$ by the red cell mass probably explain why increased free iron losses were not found by whole body counting. The investigation of free iron loss requires a sensitive double isotope ${ }^{(51} \mathrm{Cr}$ and $\left.{ }^{59} \mathrm{Fe}\right)$ faecal recovery method (Sutton and Baird, 1972). Increased free iron loss, together with malabsorption of dietary iron, appear to be important factors in the gradual onset of iron deficiency (Sutton et al, 1970). Attention should be directed to determining the site of bleeding in patients shown to have blood loss after partial gastrectomy, as it is likely to be an uncomplicated sequel of the partial gastrectomy.

D.R.S. was the holder of a research fellowship from the North West Metropolitan Regional
Hospital Board. The work formed part of a London MD thesis.

\section{References}

Baird, I. M., Blackburn, E. K., and Wilson, G. M. (1959). The pathogenesis of anaemia after partial gastrectomy: 1. Development of anaemia in relation to time after operation, blood loss and diet. Quart. J. Med., 28, 21-34.

Baird, I. M., St. John, D. J. B., and Nasser, S. S. (1970). Role of occult blood loss in anaemia after partial gastrectomy. Gut, 11, 55-61.

Baird, I. M., and Wilson, G. M. (1959). The pathogenesis of anaemia after partial gastrectomy. 2. Iron absorption after partial gastrectomy. Quart. J. Med., 28, 35-41.

Holt, J. M., Gear, M. W. L., and Warner, G. T., (1970). The role of chronic blood loss in the pathogenesis of postgastrectomy iron deficiency anaemia. Gut, 11, 847-850.

Holt, J. M., Mayet, F. G. H., Warner, G. T. and Callender, S. T. (1967). Brit. med. J., 4, 86-88.

Kimber, C., Patterson, J. F., and Weintraub, L. R. (1967). The pathogenesis of iron deficiency anemia following partial gastrectomy. J. Amer. med. Ass., 202, 935-938.

Stevens, A.R.,Jr., Pirzio-Biroli, G., Harkins, H. N., Nyhus, L. M., and Finch, C. A. (1959). Iron metabolism in patients after partial gastrectomy. Ann. Surg., 149, 534-538.

Sutton, D. R., Baird, I. M., Stewart, J. S., and Coghill, N. F. (1970). 'Free' iron loss in atrophic gastritis, post-gastrectomy states, and adult coeliac disease. Lancet, 2, 387-390.

Turnberg, L. A. (1966). The absorption of iron after partial gastrectomy. Quart. J. Med., 35, 107-118.

Warner, G. T., and Oliver, R. (1966). A whole-body counter for clinical measurements utilising the 'Shadow-Shield' technique. Phys. in Med. Biol., 11, 83-94. 